\title{
Analysis of the Influence of Public Participation Against the Success of Community-Based Sanitation Program (SANIMAS) in Paciran Village, Paciran District, Lamongan Regency
}

\author{
Dhiyas Yudi Prakoswo ${ }^{1}$ and Bambang Syairudin ${ }^{1}$
}

\begin{abstract}
Sanimas program in East Java province has been implemented from 2003 and based on the results of monitoring conducted on the sustainability of the Sanimas program as much as $30 \%$ work only partially and $8 \%$ does not work. Failure in achieving the result of the development program did not reach the target due to lack of community participation In 2017, the Directorate General of Human Settlements, the Ministry of Public Works and Housing has a project in the form of community-based Sanitation development (SANIMAS) located in Paciran village, Paciran district, Lamongan regency, which is a communal waste water treatment with an initial number of users 55 patriarch. The SANIMAS Program in Paciran Village can be assessed successfully because it still works well and is able to increase its service number significantly. There were 93 new participant in the period of 1 year so that the total users reached 148 patriarch.

This research is to examine dominant factors in the community participation that affects to the success of the Sanimas program in Paciran village. Start by spreading the questionnaires to the resident of Paciran village who participated in the SANIMAS program. Once collected data is further analyzed with a quantitative descriptive approach. SPSS analysis tools are used to determine the factors by analyzing internal factors including age variables, gender, occupation, amount of income, number of families, education level, and knowledge of SANIMAS. While the external factors include the role of local governments, the role of village government, the role of community leaders, the role of facilitators/ consultants and the role of regional regulations/ LAWS.

From the results of analysis obtained the dominant internal factors affecting the form and level of community participation is age, knowledge SANIMAS, the amount of income, type of work, level of education and the number of families. While the dominant external factors affecting the form and the level of community participation is the local regulation/ law and local government. The proposed policy to increase the success achievement of the SANIMAS program in Paciran village is that $K P P$ will routinely held a meetings with $R T$ and $R W$ and to find solutions related to emerging issues and socialization to citizens will be conducted with the approach of citizen activities such as community gathering, moslem recitation etc.
\end{abstract}

Keywords-Public Participation, Community-based Sanitation (SANIMAS), Infrastructure, Descriptive quantitative analysis.

\section{INTRODUCTION}

Failure in achieving the results of the development program did not reach the target due to lack of community participation. Participatory development is development of a positioning the community as the subject of the above development programme allocated its own community as well as the interests of the community are actively involved. Public participation aims to find the solution of the problem, which is better in a community, in this case can be done by opening up more opportunities for the community to contribute so that the implementation of the activities running more effective, efficient and sustainable. In the year 2017, Directorate General of Human Settlements, Ministry of Public Works and Housing through the Project Unit of Environmental Sanitation Systems Development of East Java has a project in the form of community-based Sanitation development (SANIMAS) in 6 Counties/cities in East Java. The SANIMAS program priority areas that are in the red zone sanitation Sanitation Strategies based on City/County (SSK), one of which is located in Paciran village, Paciran district, Lamongan regency. The SANIMAS program is a communal waste water treatment plant in Paciran village with number of users early 55 patriarch or 281 inhabitants. The SANIMAS program in Paciran village can be rated successful since it was able to increase the number of its services significantly. There are 93 patriarch recorded as new users within 1 year bringing the total users reached 148 patriarch. The Government of Lamongan regency as one of the recipients of the SANIMAS program is very appreciative to the program in supporting the Central Government by providing funds sharing in local budgets since the year 2015. It is an effort of the local government to minimize open defecation and improve the access to sanitation in the district.

${ }^{1}$ Dhiyas Yudi Prakoswo and Bambang Syairudin are with Department of Management Technology, Institut Teknologi Sepuluh Nopember, Surabaya, 60264, Indonesia. E-mail: diaz.yudip@gmail.com 
The $1^{\text {st }}$ International Conference on Business and Management of Technology (IConBMT)

August 3rd 2019, Institut Teknologi Sepuluh Nopember, Surabaya, Indonesia

\section{METHOD}

\section{A. Data Collection}

There were 2 collected data which divided into primary and secondary. Primary data is a directly obtained from study location in which on communal waste water treatment plant (SANIMAS) program in Paciran village, regarding facilities, subject, and manager. Data was collected by direct observation and interviews on authorized personal. Questionaires were also spread to obtain data from resident of Paciran village. Secondary data is usually a document and regulation which related to the study. It can be obtained from badan pusat statistik (BPS) in a form of population number, households, and total area of Paciran village. Scheaffer formulation is used to determine total sample number[1] : $n=\frac{N}{(N-1) \delta^{2}+1}$ with population $(\mathrm{N})$ as much as 148 and $10 \%$ margin of error $(\delta)$. According to the formula, minimum sample taken was $n=59,91 \approx 60$. simple random sampling was used, where every individual has the same opportunity to be randomly taken. The questionaires were given to 60 respondent who participated in the SANIMAS program.

\section{B. Descriptive Analysis}

The analysis method used in this study was descriptive analysis. Descriptive statistics is part of the statistical analysis that examines the ways of data collection and presentation of data so that it is easy to understand. Descriptive statistics only relate to it elaborates or provides information about a data or circumstances. With the words of descriptive statistics functions describe the condition, symptoms or problems. The withdrawal of the conclusions on descriptive statistics (if any) is only aimed at the collection of existing data. Descriptive analysis consists of Frequencies, Descriptive, Explore, Crosstabs and Ratio. Analysis-the analysis already exist at the option menu in statistical data processing software often used was SPSS.

Crosstabs from some of test methods that commonly used is chi-square test to find out the relationship between the rows and columns. The purpose of testing method using Chi-Square test $\left(\mathrm{X}^{2}\right)$ is to compare between facts derived based on the results of observation and fact based theoretically

\section{RESULT AND DISCUSSION}

Researched data variables approppriateness was tested by validity test and reliability test. The result has shown $\mathrm{r}$ count > $\mathrm{r}$ table and alpha cronbach > 0,60-0,80 (high reliability), the collected variable then feasible to be processed furthermore.

TABLE 1.

VALIDITY TEST

\begin{tabular}{|c|c|c|c|c|c|}
\hline Aspect & Phase/ Factor & Variable & r-table & r-count & Conclusion \\
\hline \multirow{15}{*}{$\begin{array}{l}\text { Form and level of community } \\
\text { participation }\end{array}$} & \multirow{5}{*}{ Planning } & Presence on meeting & 0,3061 & 0,621 & Valid \\
\hline & & Active in discussions & 0,3061 & 0,763 & Valid \\
\hline & & Giving suggestion & 0,3061 & 0,866 & Valid \\
\hline & & Giving donation & 0,3061 & 0,788 & Valid \\
\hline & & Follow the activities & 0,3061 & 0,809 & Valid \\
\hline & \multirow{5}{*}{ Implementation } & Presence on meeting & 0,3061 & 0,800 & Valid \\
\hline & & Active in discussions & 0,3061 & 0,799 & Valid \\
\hline & & Giving suggestion & 0,3061 & 0,881 & Valid \\
\hline & & Giving donation & 0,3061 & 0,613 & Valid \\
\hline & & Follow the activities & 0,3061 & 0,877 & Valid \\
\hline & \multirow{5}{*}{ Operational, maintenance and sustainability } & Presence on meeting & 0,3061 & 0,499 & Valid \\
\hline & & Active in discussions & 0,3061 & 0,781 & Valid \\
\hline & & Giving suggestion & 0,3061 & 0,704 & Valid \\
\hline & & Giving donation & 0,3061 & 0,696 & Valid \\
\hline & & Follow the activities & 0,3061 & 0,653 & Valid \\
\hline \multirow{5}{*}{$\begin{array}{l}\text { Forms that affect the level of } \\
\text { community participation }\end{array}$} & \multirow{5}{*}{ External factor } & Local government & 0,3061 & 0,818 & Valid \\
\hline & & Village government & 0,3061 & 0,822 & Valid \\
\hline & & Community leaders & 0,3061 & 0,932 & Valid \\
\hline & & Facilitator/ consultants & 0,3061 & 0,842 & Valid \\
\hline & & Local regulation/ law & 0,3061 & 0,765 & Valid \\
\hline
\end{tabular}


TABLE 2.

RELIABILITY TEST

\begin{tabular}{|c|c|c|c|c|}
\hline Aspect & Phase/ Factor & Variable & Alpha cronbach & Conclusion \\
\hline \multirow{15}{*}{$\begin{array}{l}\text { Form and level of community } \\
\text { participation }\end{array}$} & \multirow{5}{*}{ Planning } & Presence on meeting & 0,789 & High reliability \\
\hline & & Active in discussions & 0,790 & High reliability \\
\hline & & Giving suggestion & 0,778 & High reliability \\
\hline & & Giving donation & 0,785 & High reliability \\
\hline & & Follow the activities & 0,785 & High reliability \\
\hline & \multirow{5}{*}{ Implementation } & Presence on meeting & 0,781 & High reliability \\
\hline & & Active in discussions & 0,787 & High reliability \\
\hline & & Giving suggestion & 0,781 & High reliability \\
\hline & & Giving donation & 0,786 & High reliability \\
\hline & & Follow the activities & 0,781 & High reliability \\
\hline & \multirow{5}{*}{$\begin{array}{l}\text { Operational, maintenance and } \\
\text { sustainability }\end{array}$} & Presence on meeting & 0,794 & High reliability \\
\hline & & Active in discussions & 0,788 & High reliability \\
\hline & & Giving suggestion & 0,785 & High reliability \\
\hline & & Giving donation & 0,785 & High reliability \\
\hline & & Follow the activities & 0,793 & High reliability \\
\hline \multirow{5}{*}{$\begin{array}{l}\text { Forms that affect the level of } \\
\text { community participation }\end{array}$} & \multirow{5}{*}{ External factor } & Local government & 0,793 & High reliability \\
\hline & & Village government & 0,806 & High reliability \\
\hline & & Community leaders & 0,797 & High reliability \\
\hline & & Facilitator/ consultants & 0,794 & High reliability \\
\hline & & Local regulation/ law & 0,793 & High reliability \\
\hline
\end{tabular}

TABLE 3.

INTERNAL FACTOR PEARSON CHI SQUARE VALUE IN PLANNING PHAS

\begin{tabular}{lcccccccccc}
\hline \hline \multirow{2}{*}{ Variable } & \multicolumn{2}{c}{ Presence on meeting } & \multicolumn{2}{c}{ Active in discussions } & \multicolumn{2}{c}{ Giving suggestion } & \multicolumn{2}{c}{ Giving donation } & \multicolumn{2}{c}{ Follow the activities } \\
\cline { 2 - 11 } & $X^{2}$ & $\mathbf{d f}$ & $X^{2}$ & $\mathbf{d f}$ & $X^{2}$ & $\mathbf{d f}$ & $X^{2}$ & $\mathbf{d f}$ & $X^{2}$ & $\mathbf{d f}$ \\
\hline Age & 19,790 & 9 & 11,848 & 12 & 22,476 & 12 & 20,215 & 12 & 6,970 & 9 \\
Gender & 6,280 & 3 & 2,675 & 4 & 2,937 & 4 & 8,792 & 4 & 1,937 & 3 \\
Occupation & 23,352 & 15 & 17,728 & 20 & 17,660 & 20 & 33,132 & 20 & 14,976 & 15 \\
Amount of income & 16,740 & 9 & 18,423 & 12 & 15,714 & 12 & 14,368 & 12 & 4,574 & 9 \\
Number of families & 14,680 & 12 & 18,127 & 16 & 13,998 & 16 & 22,983 & 16 & 14,855 & 12 \\
Education & 7,808 & 12 & 16,510 & 16 & 10,125 & 16 & 16,823 & 16 & 11,814 & 12 \\
Knowledge of SANIMAS & 8,818 & 9 & 13,329 & 12 & 11,339 & 12 & 24,643 & 12 & 9,347 & 9 \\
\hline \hline
\end{tabular}

TABLE 4.

INTERNAL FACTOR PEARSON CHI SQUARE VALUE IN IMPLEMENTATION PHASE

\begin{tabular}{lcccccccccc}
\hline \hline \multirow{2}{*}{ Variable } & \multicolumn{2}{c}{ Presence on meeting } & \multicolumn{2}{c}{ Active in discussions } & \multicolumn{2}{c}{ Giving suggestion } & \multicolumn{2}{c}{ Giving donation } & \multicolumn{2}{c}{ Follow the activities } \\
\cline { 2 - 11 } & $X^{2}$ & df & $X^{2}$ & df & $X^{2}$ & df & $X^{2}$ & df & $X^{2}$ & df \\
\hline Age & 5,924 & 6 & 7,863 & 9 & 17,759 & 9 & 11,525 & 9 & 7,897 & 9 \\
Gender & 3,958 & 2 & 4,819 & 3 & 1,818 & 3 & 4,902 & 3 & 3,086 & 3 \\
Occupation & 15,541 & 10 & 37,982 & 15 & 15,627 & 15 & 16,230 & 15 & 19,114 & 15 \\
Amount of income & 9,774 & 6 & 11,068 & 9 & 12,113 & 9 & 5,340 & 9 & 12,743 & 9 \\
Number of families & 10,717 & 8 & 10,833 & 12 & 20,281 & 12 & 13,491 & 12 & 12,573 & 12 \\
Education & 16,797 & 8 & 14,300 & 12 & 12,938 & 12 & 9,484 & 12 & 15,599 & 12 \\
Knowledge of SANIMAS & 23,453 & 6 & 16,314 & 9 & 9,454 & 9 & 13,765 & 9 & 15,246 & 9 \\
\hline \hline
\end{tabular}


The $1^{\text {st }}$ International Conference on Business and Management of Technology (IConBMT)

August 3rd 2019, Institut Teknologi Sepuluh Nopember, Surabaya, Indonesia

TABLE 5 .

INTERNAL FACTOR PEARSON CHI SQUARE VALUE IN OPERATIONAL, MAINTENANCE AND SUSTAINABILITY PHASE

\begin{tabular}{|c|c|c|c|c|c|c|c|c|c|c|}
\hline \multirow{2}{*}{ Variable } & \multicolumn{2}{|c|}{ Presence on meeting } & \multicolumn{2}{|c|}{ Active in discussions } & \multicolumn{2}{|c|}{ Giving suggestion } & \multicolumn{2}{|c|}{ Giving donation } & \multicolumn{2}{|c|}{ Follow the activities } \\
\hline & $X^{2}$ & df & $X^{2}$ & df & $X^{2}$ & df & $X^{2}$ & df & $X^{2}$ & df \\
\hline Age & 4,343 & 6 & 6,260 & 9 & 7,767 & 12 & 20,506 & 12 & 16,593 & 6 \\
\hline Gender & 0,533 & 2 & 2,447 & 3 & 6,241 & 4 & 4,723 & 4 & 0,710 & 2 \\
\hline Occupation & 18,490 & 10 & 15,758 & 15 & 17,921 & 20 & 30,824 & 20 & 16,800 & 10 \\
\hline Amount of income & 5,085 & 6 & 25,113 & 9 & 23,268 & 12 & 20,433 & 12 & 12,841 & 6 \\
\hline Number of families & 6,536 & 8 & 6,921 & 12 & 9,081 & 16 & 20,508 & 16 & 22,458 & 8 \\
\hline Education & 7,032 & 8 & 17,619 & 12 & 22,510 & 16 & 24,085 & 16 & 6,435 & 8 \\
\hline Knowledge of SANIMAS & 7,930 & 6 & 8,173 & 9 & 12,520 & 12 & 24,782 & 12 & 10,289 & 6 \\
\hline
\end{tabular}

TABLE 6.

EXTERNAL FACTOR PEARSON CHI SQUARE VALUE

\begin{tabular}{lcccccccccc}
\hline \hline \multirow{2}{*}{ Variable } & \multicolumn{2}{c}{ Local government } & \multicolumn{2}{c}{ Village government } & \multicolumn{2}{c}{ Community leaders } & \multicolumn{2}{c}{ Facilitator/ consultants } & \multicolumn{2}{c}{ local regulation/ law } \\
\cline { 2 - 10 } & $X^{2}$ & $\mathbf{d f}$ & $X^{2}$ & $\mathbf{d f}$ & $X^{2}$ & $\mathbf{d f}$ & $X^{2}$ & df & $X^{2}$ & df \\
\hline Age & 7,388 & 6 & 9,611 & 9 & 5,363 & 6 & 11,092 & 9 & 18,401 \\
Gender & 2,008 & 2 & 7,801 & 3 & 2,756 & 2 & 0,693 & 3 & 1,076 & 3 \\
Occupation & 4,514 & 10 & 17,665 & 15 & 7,515 & 10 & 11,326 & 15 & 14,903 & 15 \\
Amount of income & 6,927 & 6 & 3,982 & 9 & 12,305 & 6 & 7,190 & 9 & 3,898 & 9 \\
Number of families & 7,417 & 8 & 13,056 & 12 & 3,926 & 8 & 13,534 & 12 & 9,657 & 12 \\
Education & 11,377 & 8 & 15,460 & 12 & 5,486 & 8 & 14,916 & 12 & 14,932 & 12 \\
Knowledge of SANIMAS & 13,860 & 6 & 5,151 & 9 & 10,419 & 6 & 12,480 & 9 & 15,666 & 9 \\
\hline \hline
\end{tabular}

\section{CONCLUSION}

1. The dominant influence of internal factors in the achievement of the success of the program SANIMAS in the village of Paciran sequentially from the highest are:

a. The age that affect 4 variable form and level of public participation that is that is the presence in the meeting at planning phase, give suggestion in the meetings at planning phase, give suggestion in the meeting at implementation phase and following the activities at operational, maintenance and sustainability phase.

b. Knowledge of SANIMAS that affect 3 variable form and level of public participation that is contributed in the form of labor or money at planning phase, the presence in the meeting at implementation phase and give a donation in the form of energy or money at operations, maintenance and sustainability phase.

c. The amount of income that affect 3 variable form and level of public participation that is actively discussing in meetings, give suggestion in the meeting and the following activities at operations, maintenance and sustainability phase.

d. The occupation that affect 3 variable form and level of public participation that is contributed in the form of labor or money at the planning phase, active discussions in a meeting at implementation phase and the presence in the meeting at operational, maintenance and sustainability phase. e. The education that affect 1 variable form and level of public participation that is attendance in meetings at implementation phase.

f. The number of families that affect 1 variable form and level of public participation that is following the activities at operational, maintenance and sustainability phase

2. While external factors affecting dominant form and level of public participation in the program SANIMAS in the village of Paciran sequentially from the highest is the role of local regulations/ACT with Chi-Square count of 18.401 and the role of local governments with the ChiSquare count of 13.860 .

\section{ACKNOWLEDGEMENT}

Researcher would like to thank the government and the society of Paciran Lamongan Regency who had been supporting the study.

\section{REFERENCES}

R. L. Scheaffer, W. Mendenhall, and L. Ott, Elementary Survey Sampling, 5th ed. Belmont: Duxbury Press, 1996. 